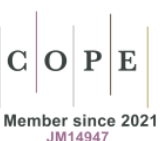

Multicultural Shakespeare:

Translation, Appropriation and Performance vol. 23 (38), 2021

https://doi.org/10.18778/2083-8530.23.05

Natalia Khomenko*

\title{
From Social Justice to Metaphor: The Whitening of Othello in the Russian Imagination ${ }^{1}$
}

\begin{abstract}
Othello was the most often-staged Shakespeare play on early Soviet stages, to a large extent because of its ideological utility. Interpreted with close attention to racial conflict, this play came to symbolize, for Soviet theatres and audiences, the destructive racism of the West in contrast with Soviet egalitarianism. In the first decades of the twenty-first century, however, it is not unusual for Russian theatres to stage Othello as a white character, thus eliminating the theme of race from the productions. To make sense of the change in the Russian tradition of staging Othello, this article traces the interpretations and metatheatrical uses of this character from the early Soviet period to the present day. I argue that the Soviet tradition of staging Othello in blackface effectively prevented the use of the play for exploring the racial tensions within the Soviet Union itself, and gradually transformed the protagonist's blackness into a generalized metaphor of oppression. As post-collapse Russia embraced whiteness as a category, Othello's blackness became a prop that was entirely decoupled from race and made available for appropriation by ethnically Slavic actors and characters. The case of Russia demonstrates that staging Othello in blackface, even when the initial stated goals are those of racial equality, can serve a cultural fantasy of blackness as a versatile and disposable mask placed over a white face.
\end{abstract}

Keywords: Othello, blackface, Russian theatre, Russian film, Soviet theatre, Soviet film, adaptation, translation, Sergei Iutkevich, Eldar Riazanov, Aleksei Zernov, Nikolai Koliada, Petr Gladilin, Vahram Papazian

On December 12, 2020, a new production of Othello directed by Andrei Goncharov opened at Moscow's famous Taganka Theatre. The production cast the white Russian actor Roman Kolotukhin to play Othello as a white man, claiming to have removed the unnecessary "theme of race conflict" ("V novom

* York University, Toronto, Canada.

1 The writing of this article was supported by generous funding from York University. 
'Otello"'). ${ }^{2}$ As startling as Goncharov's staging decision might be for the Western audience, Othello's whiteness has been, by now, normalized on Russian stages. Othello was white, blond, and dressed in a uniform "vaguely reminiscent of neo-Nazism," in a 2000 production at the Vakhtangov Theatre in Moscow (Romantsova); he was also presented as a white character at the Kazan Theatre for Young Audiences in 2011 ("V TIUZE novyi 'Otello"') and at the Regional Drama Theatre in Khabarovsk in 2013 (Rosliakova). Over the last decade, Russian theatre directors have also increasingly argued for the historical accuracy of such casting. Khabarovsk's Vladimir Orenov relied on the familiar argument that the part of Othello had been intended for white actors, explaining in an interview, "In the first productions, Othello was not black. Then, in the twentieth century, during the times of Ku-Klux-Klan, this part started to be performed by black actors" (Rosliakova). Looking back at the white performers of the early modern English theatre, this explanation, paradoxically, imagines Othello's blackness as a cultural consequence of American racism and therefore unnecessary in Russia. The Kazan Theatre for Young Audiences and, most recently, the Taganka Theatre have asserted in their press releases that the prototype for Shakespeare's protagonist was an Italian by the name of Maurizio Othello, and his blackness in the play resulted from a misinterpretation of "Maurizio" as "Moor."3

Taken together, these recent Russian productions show a tendency to exorcise the spectre of blackness from Othello, claiming the protagonist as a European whose narrative can be unproblematically appropriated by white actors. This tendency is particularly incongruous considering the significance of Othello as a black character for Russia's much-publicized anti-racism stance throughout its Soviet past. To make sense of the change in the Russian tradition of staging Othello, this article traces the interpretations and metatheatrical uses of this character from the early Soviet period to the present day. I argue that the Soviet tradition of staging Othello in blackface effectively prevented the use of the play for exploring the racial tensions within the Soviet Union itself, and gradually transformed the protagonist's blackness into a generalized metaphor of oppression, un-moored from race. The case of Russia ultimately demonstrates

${ }^{2}$ All translations from Russian are mine unless otherwise indicated. This paper uses the Cambridge University Library version of the ALA-LC transliteration scheme, unless an accepted spelling already exists for Russian names.

3 This belief, so popular in Russia that it is reflected in the Russian Wikipedia's entry on Othello, seems to be a garbled hybrid of two Western attempts to find a white prototype for the protagonist: St. Vincent Troubridge's "distinguished Venetian soldier called Maurizio Othello, who migrated to Hungary, where he was known as Othello Mor, Mor being the Hungarian for Maurizio" (Ackermann 485) and Rawdon Brown's Cristoforo Moro, a Venetian lieutenant who served in Cyprus (Ruskin 353). 
that staging Othello in blackface, even when the initial stated goals are those of racial equality, can serve a cultural fantasy of blackness as an artificial and disposable mask placed over a white face.

\section{Othello and racial oppression: Embracing blackness in Soviet Russia}

Othello was the most frequently performed of all Shakespeare plays during the early Soviet period, ranked the most-staged play in the Soviet Union in 1939 (Kruti 2). An important part of the play's appeal was the possibility of reading it as a tragic narrative of the protagonist's extreme marginalization by the Western world. As a review of Sergei Radlov's 1935 Othello at the Maly Theatre explains, the black protagonist should be seen as "entangled in the civilized world's deceit and hypocrisy" and, consequently, as experiencing "resentment and hatred of a person belonging to an oppressed race [...] surrounded by enemies" (Alpers 314). The murder of Desdemona is viewed as a means to "restore the disrupted justice" and take "revenge for the deceit, for the black guile of the honey-tongued people with white skin and predatorial claws" (Alpers 315). Emerging from the Soviet Union's own embattled position in relation to the capitalist West, this reading created an opportunity for Soviet audiences to reflect on their own mythologized rise against oppression in order to build a just world of socialism. The review, accordingly, notes that interpreting Othello through the lens of race made the protagonist "wonderfully relatable for the Soviet audience" (Alpers 315).

Discussing the Western "critical and cultural fixation on Shakespeare's tragedy of inter-racial marriage," Celia Daileader introduces the term Othellophilia in reference to the play's use as a cautionary tale to white women and as an instrument of assuaging the collective sexual guilt after the abolition of slavery (6 and 8-9). While the Soviet Union similarly fixated on the play, Othello's blackness became a signifier for a marginalized individual's struggle for justice and against social oppression, with the death of Desdemona usually presented as an inevitable casualty on the path toward future equality. This reading of Othello was closely intertwined with the scientific discussion of race, and with the Soviet Union's self-proclaimed status as a multi-ethnic state of fraternal nations. In the 1930s, Soviet scientists took a stand opposing the theories of racial essentialism that were being developed by Hitler's Germany (Hirsch 263-264). They saw physiological distinctions between races as generated by distinct geographical conditions and destined to disappear through the intermarriage that would become more frequent as social development progressed (Hirsch 264-265). By expressing its approval for intermarriage, promoting equality for all peoples inhabiting its territory (Martin), and extending 
support to racialized groups around the world, including the United States and Africa, the Soviet Union both claimed for itself a position of greater social advancement within the Marxist view of history and undermined the strident German claim to cultural superiority. When staged with appropriate attention to race and racial tensions, Othello thus became a useful propaganda piece depicting the evils of racism in countries that held to the belief of biological determinism, and simultaneously highlighting the virtue of Soviet egalitarianism.

Despite the Soviet theatre's lofty aspirations, the part of Othello continued to be performed almost exclusively in blackface, and Aleksandr Ostuzhev, a Russian actor who played the protagonist in Radlov's 1935 production, was no exception. There were several reasons for this. Russia had no significant history of racialized slavery, although it was not unusual for wealthy families, including the royal household, to include some black employees, some of them originally brought in through the slave trade (Gnammankou 67-70). Russian serfs had no freedom of movement, were routinely bought and sold, and suffered violence-including sexual violence-without redress, but it was class rather than skin colour that separated the serfs from their owners. Accordingly, blackface minstrelsy and burlesque representations of black Shakespearean actors were absent from the nineteenth-century Russian theatrical tradition. ${ }^{4}$ Face-painting was therefore assumed to be a viable and neutral approach to playing a character of different race; indeed, Ira Aldridge's use of whiteface to play Macbeth, King Lear, and Richard III while touring Russia was accepted without question (Kujawinska Courtney 114-116). This assumption was coupled, in the 1930s, with a shortage of black actors capable of speaking Russian with the fluency necessary for delivering Shakespearean text. The one exception was Wayland Rudd, a black American actor with previous experience of playing Othello who made his way to Moscow in 1932 as part of the group invited to work on the film Black and White. Although the film was never made, and most of the cast members left the Soviet Union, Rudd stayed behind, taking part in a number of plays and films over the years. As a new Russian speaker, he was not entrusted with the part of Othello until much later. On February 6, 1945, Nikolai Mordvinov, celebrated for his Othello at the Mossovet Theatre, recorded in his diary that the theatre had just hired Rudd for the part, adding: "Well, so be it, this is interesting. Perhaps he will give me tips on how to play [this character]." Notably, Mordvinov's rueful remark acknowledges the possibility of Rudd's greater suitability for playing a black character but does not interrogate his own position as a white actor, assuming that with some "tips" he will be able to mount a persuasive performance of Othello's blackness.

4 For comparison, see Robert Hornback's instructive discussion of blackface minstrelsy on American stages and of burlesques aimed at black actors playing Shakespeare (chapters 4 and 7), as well as Kris Collins. 
An additional motivation for Soviet theatre's embrace of blackface in staging Othello, even as it denounced the Venetian characters' racism, was its reluctance to recognize the racial or ethnic tensions within the Soviet Union itself. While actors belonging to the so-called "national minorities" across the Soviet territory often played the part, they did so in black make-up, thus emphasizing that the play's conflict could not be linked to the group which they represented. Vahram Papazian, the Soviet Armenian actor internationally known for his Othello, is a case in point. Papazian toured Moscow and Leningrad in the late 1920s with a performance that pioneered a race-oriented reading of Othello on the Soviet stage. In the interviews printed in Russian periodicals, Papazian identified as a national minority $(1928,417)$ and, in his later autobiography, described having to wear face-paint, a blond wig and false beard, and an artificial nose in order to play a Russian character while in Constantinople $(1937,216)$. But despite the actor's racialized status as an Armenian in a cultural space that was almost entirely ethnically Slavic, Papazian played Othello under a thick layer of dark paint. The use of blackface created the illusion, however unstable, that the conflict addressed in the play had no equivalent in the Soviet Union, and that the actor's body under this disguise was shaped only by his Soviet subjecthood, not by racial history or ethnic roots.

The 1955 film adaptation of Othello, directed by Grigori Kozintsev's erstwhile collaborator Sergei Iutkevich in 1955, recorded the Soviet vision of the protagonist's struggle for freedom and his suffering humanity performed by a white Russian actor in startlingly unrealistic blackface. ${ }^{5}$ Upon completing the film, Iutkevich produced a lengthy essay that castigates the Western academia and theatre for reducing the play's plot to an allegorical struggle between good and evil, and for attempting either to "whiten" Othello or to use race as an explanation for his downfall (98-99 and 103-104). Iutkevich argues, on the contrary, that "Othello is deliberately introduced by the playwright as an outsider character" and thereby freed from all feudal duties and bonds that would have otherwise restricted his growth (100). Prudently referencing Marx and Engels, this reading establishes Othello as "the humanist ideal that Shakespeare was seeking," and interprets his "military biography" as evidence of "social usefulness" and of his position "as an active life-builder [zhiznestroitel']" (101). In Iutkevich's Othello, the protagonist's blackness, highlighted throughout the film, functions as a marker of his inner freedom: as the director notes, "Our film opens with Othello's black hand resting on a globe..." (131). This artificial blackness is almost immediately associated with communist symbolism, as Othello then appears in Desdemona's mind's eye clad

${ }^{5}$ See a recent re-evaluation of the film by Boris Gaydin. 
in vibrant red. ${ }^{6}$ The visual association with communist struggle is reinforced as the figure of Othello is repeatedly coupled with the red Venetian flag during the opening sequence. He first brandishes it while fighting Turks, and then is proudly positioned on the prow of his ship for a long shot against the red background of the flag. In the visual logic of the film, the protagonist's blackness is made meaningful when framed in the red of the communist struggle and performed by a Soviet actor. This framing is reiterated in Iutkevich's decision to make the handkerchief black and red. The audience first sees it clearly as it is pressed by Desdemona's hand against the shoulder of her husband, as a visual echo of his black cloak with bright-red lining. As "a material or textile body" (Smith 4), Iutkevich's black-and-red handkerchief calls into being an ideological fantasy of the hybrid black-and-Soviet body.

Iutkevich's film's treatment of Act 5, scene 2, emphasizes the injury done to Othello and his subsequent suffering rather than Desdemona's death, and insists on the protagonist's victory rather than downfall, in line with the director's argument that the "immediate emotional outcome of this tragedy consists in the pathos of fighting for truth" (96, emphasis in the original). The film works to exonerate the protagonist and to confirm his value for the Soviet culture. Accordingly, Desdemona's death is not shown to the audience: after Othello places a pillow on his wife's face, the shot changes immediately to show a candle blowing out and then then willow branches blowing tempestuously against a dark sky. As Othello cautiously emerges from the bed in the next shot, the view of Desdemona's body is blocked by a heavy brocade curtain. Throughout the scene, Othello and then Emilia draw the curtain aside to look at the bed, but an "ocular proof" of the unjust murder is withheld from the audience except for a brief glimpse of Desdemona laid out in the manner of a tomb effigy. ${ }^{7}$ The transformation of Desdemona's body into a funereal image is completed when, after the revelation of Iago's crime, Othello carries the corpse of his wife to the roof of the castle and lays her out on a stone slab. Sitting at her feet, Othello is presented not as a murderer but as a mourner grieving his loss - an impression that is strengthened by his hair turning completely white during the time that has elapsed since the murder. The dying Othello's proud silhouette, looking out from the roof's edge and framed by the dawn, becomes the embodiment of what Iutkevich saw as the play's prophetic "protest against deceit, against all untruth, and all hypocrisy" (96, emphasis in the original).

${ }^{6}$ Iutkevich speaks of "red, black, white" as the three main visual themes of the film (132). In the epilogue, Othello, as he is laid out on Lodovico's ship about to be transported to Venice, is again dressed in red.

7 The film, probably unknowingly, reproduces some of the post-Restoration attempts to emphasize Othello's nobility on stage, described by James R. Siemon. 


\section{Metatheatrical Othello: Blackness as a metaphor}

Iutkevich's film delivered what, by the 1950s, had become a recognizable Soviet vision of Othello: the white actor's blackface signifying a struggle for liberty and for social justice. However, so palpable were the director's efforts to map the play on the Marxist vision of history and on the Soviet foreign policy, that the protagonist's blackness no longer served to represent racialized bodies and instead functioned as a discernibly artificial vehicle for social messaging. By the last decades of the Soviet regime, ideological readings of the play made Othello's blackness available as a metaphor of striving for personal agency and recognition within an openly hostile society. In Eldar Riazanov's cult film Speak on Behalf of the Poor Hussar (O bednom gusare zamolvite slovo, 1981), playing Othello in blackface is already used as a marker of searching for personal dignity in a police state. Safely set in the 1840s, Riazanov's film explores the abuses of power, judicial failures, and political paranoia in Tsarist Russia to obliquely satirize the suffocating atmosphere of the Soviet Union shortly before the perestroika. The film's initial conflict is set in motion during a performance of Othello at a provincial theatre in nineteenth-century Russia, as a young hussar besotted with Desdemona makes his way first backstage and then into the prompter's box. Unused to theatrical illusion, the hussar initially assumes that Bubentsov-the actor who plays Othello-is black, and cuts into the conversation between the actors with a dismissive, "Excuse me, arap." The word arap, in nineteenth-century Russia, was an equivalent of the early modern "blackamoor" but with implications of both exoticism and servitude (see Novikova 571-576). In this case, it signals Bubentsov's comical inability to maintain control over the encounter, as he must now return to the stage for his next scene with an exclamation, "Haply, for I am black..." (3.3.267). This line had previously assumed profound significance in Soviet engagement with the play, and was customarily used to draw the audience's attention to the protagonist's awareness of his own race. In 1935, Ostuzhev famously uttered it while studying his own hands, and Iutkevich's Othello looked at his own reflection in a pool of water (Iutkevich 124-125). Here, instead, Bubentsov's assertion of blackness initiates the slapstick deterioration of the blackface, as, in making a series of desperate efforts to eject the hussar from the prompter's box, the actor loses his curly wig, much of his dark face paint, and all of his noble bearing. In this failed performance of Othello, Bubentsov's supposed blackness is revealed to be a flawed mask that draws the audience's attention to his disempowered position as a white subject in Tsarist Russia and foreshadows his eventual self-sacrifice in service of greater justice.

In post-Soviet Russia, the shaping of Othello's blackness as a prop that was available for use by ethnically Russian characters aligned with the progressive racialization and criminalization of non-Slavic people, especially in 
cultural centres (Roman). Despite Russia's insistence that it was entirely free of racism, the post-collapse decades saw an increasing popular impulse to define Russian people as Slavic or "white," and to position non-Slavic migrants, regardless of their ethnicity, as "black" and potentially threatening (Zakharov ch. 5; Roman 2). Rather than finding their way into this complex conversation, post-Soviet metatheatrical engagements with Othello adopted blackface as a metaphor that was uncoupled from any concern with race and served, instead, to produce sympathy for the Slavic protagonist's aspirations and plight. The three cases I examine in the subsequent pages demonstrate this metaphorical use of blackface by revealing its instability and self-consciously focusing on the moment of its creation to mobilize the set of cultural meanings associated with Othello's fate.

In Petr Gladilin's The Moth (Motylek, 2001), set in a military garrison in northern Russia, an excerpt from Othello is staged by the garrison's middle-aged commander and a new conscript Lebedushkin, who has purportedly transformed into a woman overnight. ${ }^{8}$ Played by Polina Kutepova, Lebedushkin remains gender-ambiguous throughout the play, using masculine-inflected verbs to refer to their actions, while describing themselves as female. Situating this gender ambiguity in a military context, The Moth interrogates Russia's cult of military masculinity with its focus on preparing for a potential war rather than on developing an emotional life or building a peaceful nation (Eichler). Perhaps the clearest example of this underlying theme appears in Act 3, when the commander attempts to undermine Lebedushkin's supposedly effeminate interest in theatre by commenting: "Tomorrow, we'll be learning how to dig trenches in frozen ground. Tomorrow you will defend your Motherland!" To the conscript's objection that there is no war on, the commander forcefully responds, "That doesn't matter! There will be. Some day, there will be a war." This permanent expectation of war, and the labour associated with it, transforms male bodies into military machines, discouraging close bonds, expressions of emotion, or interest in cultural pursuits. As "a real man," the commander is not permitted to feel grief and regret, or to shed tears; by his own admission, he did not cry when his mother died, when his wife left, or when his best friend was torn into pieces by a mortar-gun. Lebedushkin's very existence, in other words, challenges the view of masculinity in which all self-expression that cannot be construed as military efficiency is dismissed as effeminate.

The re-enactment of Othello and Desdemona's emotion-charged encounter from Act 4, scene 2, further challenges the rigid boundaries of military masculinity and enables the commander to push against the narrow limits of permitted self-expression. The potential for this challenge is established

8 This paper discusses the play text as it appeared in the 2002 production directed by Evgenii Kamenkovich at the Pyotr Fomenko Workshop Theatre. 
in advance, when the commander balks at being asked to portray Othello weeping at Desdemona's imagined infidelity. In the ensuing debate, Othellowho, as Lebedushkin notes, outranks the commander-becomes a model of military masculinity that, nonetheless, allows for empathy and grieving. The commander argues, "He is a Moor, dammit! He is a black-skinned... a southern person," foregrounding blackface as an absolute necessity in the project of being liberated from the demands and expectations placed by the Motherland on his own white, "northern" body. In Act 4 of The Moth, the commander puts on the black paint gradually, beginning with several long strokes that leave him looking eerily like a commedia dell'arte character. Pausing, he stares fixedly in a mirror and mutters, "Who am I, dammit?" On the one hand, this question seems rhetorical and serves to highlight the absurdity of the situation. On the other hand, it marks the beginning of an identity shift initiated by the application of black make-up. The production makes no pretense of aiming for realism: the commander's blackface remains incomplete and mask-like, ending abruptly in the middle of his forehead, and with unpainted spaces around his eyes and mouth. It does not seek to imitate Othello's black skin per se but rather exempts its wearer from the constraints of being ethnically Russian and therefore forced to shoulder the burden of national responsibility. Having been marked, through the application of blackface, as ethnically and geographically foreign, the commander is permitted affect, tears, and human touch, even after the paint has been removed. In Act 5-now fully revealed as the protagonist of the play- the commander is able to grieve and even shed tears for the dead Lebedushkin, tragically struck down by a military car during a training drill. For the first time in his life, the commander is also empowered to rebel against the army's dispassionate treatment of soldiers' death as mere loss of resources, exclaiming, "No, no, we shouldn't do it this way, this is inhuman [ne po-liudski]."

In Aleksei Zernov's comedy film Things Undreamt of by Shakespeare (Shekspiru i ne snilos, 2007), a staging of Othello extends an offer of social recognition to a group of outcasts. The main plot, set in nineteenth-century Russia, focuses on three small-time swindlers: Lizon, Mavrodii, and Altyn (the least recognized and respected member of the group). While on the run from the enraged mob and local policemen, the trio are mistaken for a group of famous actors on their way to perform Othello in another town and roped into putting on a production of their own. They are assisted in this undertaking by a Shakespeare-loving theatre ticket seller Serafima, a single mother who is only too happy to become Desdemona for an evening. Although this film is intended as light entertainment, much of its plot is predicated on the recognition of systematic inequality and disenfranchisement. The Tsarist police, closely focused on protecting the interests of wealthy landowners, is quickly revealed as brutal and operating with deeply held class bias. The swindler trio are excluded from the social hierarchy and consigned to a life of invisibility, unless perceived as a direct threat to the social order. 
However, in taking on the part of Othello, Altyn is invested with the protagonist's power of storytelling and his ability to invoke sympathy by narrating his travails and oppressions. Indeed, Altyn's use of blackface - artificial, startling, and demanding interrogation - is explicitly presented as a symbol for active marginalization. Upon first encountering his co-conspirator in blackface, Mavrodii-set to play Iago-screams in terror, causing Altyn to comment morosely: "See what fate has done to me." As with The Moth, the audience's attention is directed to the construction of his blackface. In a glimpse of the changing room, we see Altyn fussily touching up the paint while Serafima, rehearsing Desdemona's lines in Act 3, scene 3, addresses the following question to him: "I love you, my dread lord, / But why is your face not light?" Serafima is speaking in iambic pentameter and, supposedly, reading from the copy of Othello in her hand, but these lines have no equivalent in Shakespeare's English text and do not appear in Boris Pasternak's Soviet-period translation of Othello which the film - anachronistically - uses. Presumably, the reference to Othello's face was inserted to indicate Serafima's emerging affection for Altyn, but also for its dubious pun value, since in Russian speaking of one's face being light or dark is a reference to the person's mood. The audience is expected to derive amusement from the tension between the idiomatic expression and the literal dark paint on Altyn's face. This moment, however, also serves to position blackness on the Russian stage as a culturally produced marker for the protagonist's loss of control: Serafima's future lord is dark of face because the combined pressures of police pursuit and his companions' insistence on going ahead with the performance have forced him to blacken himself.

One might say that Altyn's fears come true, since the performance predictably dissolves into chaos, but instead of disaster, his blackface-and its instability - produce a series of revelations and a cathartic reconciliation. As Serafima-as-Desdemona is working around the gaps in Altyn-as-Othello's delivery and attempting to feed him lines, he is undone by the tenderness she expresses both as a character and as an actor. Speaking in iambic pentameter, Altyn is emboldened to narrate his past travails: "Usually, everyone mocks me [...] Oh, how much I've suffered, Desdemona!" Even going off-script, Altyn is mobilizing the cluster of associations linked to the character of Othello; the admission of suffering directly alludes to the widely known Russian translation of Othello's line, "She loved me for the dangers I had passed" (1.3.168). ${ }^{9}$ When

9 The best-known version of this line in Russian, which has by now gained the status of an aphorism, derives from Petr Veinberg's 1850s translation: "Ona menia za muki poliubila" (she fell in love with me for my sufferings). This line's popularity has been, no doubt, aided by the cultural perception of Othello as a spectacularly persecuted character. 
Serafima responds with sympathy and affection, Altyn is emboldened to further imitate his character's tales of "pilgrimage" and "of some distressful stroke" that won Desdemona's heart $(1.3 .154,158)$. In order to do so, Altyn must formally acknowledge the constructed nature of his blackness and its symbolic function. Declaring his desire to confess all, he slowly unbuttons his shirt to reveal pale skin, in sharp contrast with the dark paint on his face, and takes off his curly wig. "I am not Othello," he says and, after a pause, adds, "And not even Altyn. I'm Evstignei Shumilov." What begins as a seemingly naïve distinction between character and actor, rooted in the recognizable artificiality of the actor's blackface, is quickly clarified as a deeply emotional and potentially dangerous disclosure of Altyn's real name, followed by further revelations of his criminal past. This bold disclosure of Altyn's outsider status is made coherent and acceptable by the framing device of blackface, now entirely governed by the demands of the white character. When confronted by the terrified Mavrodii-asIago, Altyn declares, "You cannot fool us, my fine fellow. / Othello is finally, for the first time in his life, happy," and replaces the wig on his head, signalling a renewal of his performance of blackness. Altyn's ability to make his distinguished audience weep in sympathy and forgiveness, as well as his insistence on deserving truth and happiness, hinges on the blackface as a visual allusion to Othello. But while invoking Othello's outsider status and longing for social acceptance, the film erases race and racial conflict as a theme. A smudge left by Altyn's blackface on Serafima's cheek — which in the Western conversation has been interpreted as an expression of anxiety about racial contagion (Menzer ch. 2)-here functions to mark Serafima as one of the dispossessed white subjects and, consequently, as deserving of recognition and reward.

Also produced in 2007, under the direction of Galina Volchek at the Sovremennik Theatre, Nikolai Koliada's play The Rabbit. Love story (Zaiats. Love story) makes this point with acerbic clarity, working to uncouple blackface from racial identity and African roots, and mounting it as an allegory of social and cultural alienation. The play's metatheatrical performance of Othello is limited to a single monologue in blackface-Othello's final speech, beginning with, "I pray you, in your letters..." (5.2.338) — and serves to appropriate the narrative of black people's oppression for the white actor playing a white character. The Rabbit takes place in a dingy provincial hotel room and depicts a confrontation between two characters: Tania, a professionally trained actor in her sixties who is eking out a living as an entertainer in Moscow, and her ex-husband Misha, formerly also an actor, whom she had long believed to be dead. Their conversation is structured as a series of mournful revelations - that Misha is not dead but has been living a life of quiet alcoholism in a small town, that Tania's career has turned into a humiliating sale of her talent to rich clients, that they still love one another, and that it is too late for them to revive this love. 
The premise for their meeting is that Tania has been invited to this nameless provincial town in order to impersonate a black singer who had not been able to fly in for her concert. Accordingly, throughout the play, the actor playing Tania appears in blackface and a gaudy "African" outfit, both of which, throughout, signify her perceived dehumanization and lack of personal agency. In a particularly dramatic monologue, she asks, rhetorically, "And why did I even need this life, if I am a black, a blackamoor, a black-assed Papuan [papuaska chernozadaia], and not a human being; if I had lived my whole life in a ghetto, on a reservation for the blackest of the black." Tania's question invokes the familiar Soviet association of blackness with oppression and marginalization in order to lament her own existence, with blackface serving as a visual signifier for the post-collapse degradation of white Russians. Within Koliada's play, invocations of racial difference are meaningful only insofar as they are applied to white individuals within an endless homogeneous expanse of the Russian cultural space.

With on-stage blackness and references to race thus emptied out of meaning, the play's metatheatrical use of Othello opens up the Soviet narrative of the racialized protagonist's struggle for liberty and truth to the white citizens of twenty-first century Russia. Notably, the first version of this play, entitled The Elderly She-Rabbit (Staraia zaichikha), published in 2006, did not reference Othello. The Shakespearean allusion was introduced when the Sovremennik Theatre gave the part of Misha to Valentin Gaft, a well-known Russian actor who had previously played Othello in blackface in Anatoly Efros's highly publicized 1978-1979 production at the Theatre on Malaia Bronnaia. The image of Gaft blacking up on stage in 2007 was inevitably haunted or ghosted, as Marvin Carlson might have put it, by his previous performance of Othello in pre-collapse Russia. Gaft's delivery of a speech from his former role strengthens the Soviet Othello's ghostly presence but, at the same time, reveals the Soviet version of this character to be a disembodied construct, whittled down to a mere touch of black paint on white skin. Indeed, Pasternak's translation cited in the production uses a metaphor of painting in its rendering of Othello's plea that the Venetians "nothing extenuate, / Nor set down aught in malice" (5.2.340-341). Pasternak's Othello instructs, "There is no need to use / Dark shading, no need to tone down the hue," implying, through this idiomatic expression, that the path toward recapturing the protagonist's experience lies in finding the right colour rather than fitting words. Gaft-as-Misha explicitly sets out to appropriate the longing for truth and freedom associated with the Soviet Othello through his on-stage creation of blackface; in the lead-up to his delivery of Othello's speech, he declares that he would also like to be "a black" and repeats several times, in higher and higher tones, "What a black I am going to be!" The nominal blackface Misha constructs-two hasty smudges on his cheeks-becomes a visual declaration of his affinity with Tania, as well as his claim to the pathos 
of Othello's heroic downfall. By creating the right "hue" through his nominal blackface and through Othello's death speech, Misha is able to lay claim to the protagonist's cathartic self-destruction in service of his love and his indifferent country. Acknowledging this claim, Tania addresses him, post-speech, "Othello! Haply you are black," and sums up their joined downfall by adding, "We have both grown so old. Two old, mangy blacks."

\section{Conclusion}

In examining the changing approaches to staging the figure of Othello in Russia over the past century, this article interrogates the implications of blackface performance in a cultural space where few black actors are available. Despite the early Soviet ideological attention to the racial tensions in Othello, the protagonist's blackface ultimately served as a device that deflected all questions raised by the play to the West while purportedly testifying for the absence of racism in Soviet Russia. To use Ayanna Thompson's terminology, Soviet theatre never attempted to instrumentalize blackface performance by querying "the relationship between practice, intention, and reception" (450). Soviet directors and actors assumed that their stated intention-to denounce Western racism -would translate into on-stage blackface as a spectacle of Soviet egalitarianism and be understood as such by the audience. Instead, as metatheatrical uses of Othello in late Soviet and post-Soviet Russia suggest, blackface came to be understood as a prop that had no immediate semiotic connection to race. The Soviet vision of Othello as suffering from marginalization and alienation while continuing a doomed, poignant struggle for truth and justice survives in Russia to the present day. However, this vision is no longer tied to Othello's racialized status; rather, his blackness has become a disguise that an actor might or might not wish to adopt. So, in Yury Butusov's Othello, which has been running at Moscow's Satirikon Theatre since 2013, characters assume blackface in the course of the performance to explore what the director calls "the black depths of the human subconscious" ("Otello").

Russia has consistently defended its right to use blackface in performance, insisting that, in a country that supposedly had no history of racial discrimination, blackface had no potential for doing harm. ${ }^{10}$ But, as this article suggests, the insidious threat of blackface in Russian culture lies precisely in its potential for obscuring racial tensions-and, paradoxically, for obscuring race altogether. In a very real sense, for decades now Russian culture has viewed the

${ }^{10}$ See, for example, the statement on social media made by Margarita Simonyan, a journalist and powerful media figure in Putin's Russia, in defense of blackface used on her husband Tigran Keosayan's comedy show. 
character of Othello as a white man who wore blackface as a more or less arbitrary signifier of his outsider status. His concerns and aims, as well as obstacles he encountered, were understood to be those of Everyman - or, more specifically, of a white Russian man operating in a cultural space also assumed to be homogenously white. The recent tendency to remove Othello's blackness altogether, sometimes citing the invented figure of Maurizio Othello, is simply the next-not entirely unexpected - stage of appropriation by a culture that refuses to examine its own history of racial and ethnic tensions.

\section{WORKS CITED}

Ackermann, A.S.E. Popular Fallacies Explained and Corrected. $3^{\text {rd }}$ ed. London: The Old Westminster Press, 1923.

Alpers, Boris. "Itogi teatral'nogo sezona (1935/36)." 1936. Teatral'nye ocherki. Vol. 2. Moscow: Iskusstvo, 1977: 312-320.

Carlson, Marvin. The Haunted Stage: The Theatre as Memory Machine. Ann Arbor: The University of Michigan Press, 2001.

Collins, Kris. "White-washing the Black-a-moor: Othello, Negro Minstrelsy and Parodies of Blackness." Journal of American Culture 19.3 (1996): 87-101.

Daileader, Celia R. Racism, Misogyny, and the 'Othello' Myth: Inter-racial Couples from Shakespeare to Spike Lee. Cambridge: Cambridge University Press, 2005.

Eichler, Maya. Militarizing Men: Gender, Conscription, and War in Post-Soviet Russia. Stanford: Stanford University Press, 2012.

Gaydin, Boris. "Sergei Yutkevich's Othello Revisited: A View from the $21^{\text {st }}$ Century." Znanie. Ponimanie. Umenie 4 (2018): 204-216.

Gnammankou, Dieudonné. "The Slave Trade to Russia." In From Chains to Bonds: The Slave Trade Revisited. Ed. Doudou Diène. Paris: UNESCO Publishing, 2001: 65-73.

Hirsch, Francine. Empire of Nations: Ethnographic Knowledge and the Making of the Soviet Union. Ithaca and London: Cornell University Press, 2005.

Hornback, Robert. Racism and Early Blackface Comic Traditions: From the Old World to the New. London: Palgrave Macmillan, 2018.

Iutkevich, Sergei. “'Otello', kakim ia ego uvidel.” In Kontrapunkt rezhissera. Moscow: Iskusstvo, 1960: 92-145.

Koliada, Nikolai. Staraia zaichikha. Ural 8 (2006). Accessed through Zhurnalnyi Zal. https://magazines.gorky.media/ural/2006/8/staraya-zajchiha.html

Kruti, I. "Sovetskii shekspirovskii teatr." Sovetskoe iskusstvo 40, 21 April 1939: 2.

Kujawinska Courtney, Krystyna. "Ira Aldridge, Shakespeare, and Color-Conscious Performances in Nineteenth-Century Europe." In Colorblind Shakespeare: New Perspectives on Race and Performance. Ed. Ayanna Thompson. New York: Routledge, 2006: 103-122.

Martin, Terry. The Affirmative Action Empire: Nations and Nationalism in the Soviet Union, 1923-1939. Ithaca: Cornell University Press, 2001. 
Menzer, Paul. Anecdotal Shakespeare: A New Performance History. London: Bloomsbury, 2015.

Mordvinov, Nikolai. Dnevniki, 1938-1966. Moscow: VTO, 1976. Accessed through Prozhito. The European University at St. Petersburg. https://prozhito.org/notes? date $=\% 221945-01-01 \% 22 \&$ diaries $=\% 5 \mathrm{~B} 44 \% 5 \mathrm{D}$

Novikova, Irina. "Imagining Africa and Blackness in the Russian Empire: From Extratextual Arapka and Distant Cannibals to Dahomey." Social Identities 19.5 (2013): 571-591.

"Otello." Satirikon. https://www.satirikon.ru/performance/repertoire/otello/ [Accessed on 23 December 2020].

Papazian, Vahram. “O sebe.” Sovremennyi teatr 21, 22 May 1928: 417.

- Po teatram mira. Ed. and intro Evgenii Kuznetsov. Leningrad/Moscow: Iskusstvo, 1937.

Roman, Meredith L. "Making Caucasians Black: Moscow Since the Fall of Communism and the Racialization of Non-Russians." Journal of Communist Studies and Transition Politics 18.2 (2002): 1-27.

Romantsova, Olga. "Vo vsem vinovaty zhenshchiny." Expert, 13 March 2000. https://expert.ru/expert/2000/10/10ex-novkult3_24087/

Rosliakova, Svetlana. "Za shtorkoi stoial belyi Otello." Grand Express 2, 9-16 January 2013. http://mail.grandex27.ru/paper/473/7370/

Ruskin, John. Ruskin's Venetian Notebooks 1849-50. Vol. 10, Stones of Venice, vol. II. Eds. Ian Bliss, Roger Garside, and Ray Haslam. Lancaster University. 2008. https://www.lancaster.ac.uk/fass/ruskin/eSoV/

Shakespeare, William. Othello. $3^{\text {rd }}$ ed. Ed. E.A.J. Honigmann. 1997. London: Arden Shakespeare, 2001.

Siemon, James R. “'Nay, that's not next': Othello, V.ii in Performance, 1760-1900." Shakespeare Quarterly 37.1 (1986): 38-51.

Simonyan, Margarita. Twitter post. 30 November 2020. https://twitter.com/ M_Simonyan/status/1333432276877774850 [Accessed on 20 December 2020].

Smith, Ian. “Othello's Black Handkerchief.” Shakespeare Quarterly 64.1 (2013): 1-25.

Thompson, Ayanna. "The Blackfaced Bard: Returning to Shakespeare or Leaving Him?" Shakespeare Bulletin 27.3 (2009): 437-456.

"V novom 'Otello' Teatra na Taganke rasovyi konflikt otsutstvuet, a Iago igraet zhenshchina.” Moskvich Mag, 12 November 2020. https://moskvichmag.ru/ gorod/v-novom-otello-teatra-na-taganke-rasovyj-konflikt-otsutstvuet-a-yago-igraet/

“V TIUZE novyi 'Otello'.” Vecherniaia Kazan', 1 February 2011. http://www.eveningkazan.ru/articles/v-tyuze-novyy-otello.html

Zakharov, Nikolay. Race and Racism in Russia. Palgrave Macmillan: Basingstoke, 2015. 